\title{
Bacteriological Failure
}

National Cancer Institute

\section{Source}

National Cancer Institute. Bacteriological Failure. NCI Thesaurus. Code C102601.

There are indicators of bacterial infection in the individual who previously had an infection. 